\title{
Identifying the strengths and weaknesses of conservation planning at different scales: the Coral Triangle as a case study
}

\author{
Jessica Cheok $^{1}$, Rebecca Weeks ${ }^{1}$ and Robert L. Pressey ${ }^{1}$
}

\begin{abstract}
Each year, hundreds of conservation plans are developed to direct limited resources toward conservation in priority areas. Conservation plans are developed at different levels, defined here as points on a range of spatial extent varying from global to local. However, approaches to integrate plans effectively across levels remain elusive. To plan across multiple levels most effectively, the relative strengths and weaknesses of planning at different levels must be understood. Taking the Coral Triangle region of the western Pacific Ocean as a case study, we apply an adapted social-ecological system (SES) framework to assess the scalar coverage of conservation plans, i.e., the extent to which plans developed at one level adequately consider the social and ecological levels and components (i.e., resource units, resource systems, governance systems, actors) of an SES. No conservation plans we assessed had complete cross-level coverage. Plans most adequately addressed social and ecological components at the same level of planning and, to a lesser extent, lower levels. In line with previous literature suggesting that social factors are most relevant at local levels, we found that local-level plans engaged with the greatest number of stakeholder groups, whereas higher level plans more adequately addressed ecological components. Given that it appears more practicable for higher level plans to consider components at lower levels, the onus should fall on higher level planning to link to lower levels. Achieving complete cross-level coverage will require vertical interactions between planning processes at different levels, and conceiving of planning processes across all levels as connected planning systems. We demonstrate how an adapted SES framework can be used by conservation planners to assess the cross-level coverage of their own plans and to formulate appropriate conservation objectives to address social and ecological components at different levels.
\end{abstract}

Key Words: conservation planning; Coral Triangle; evaluation framework; level; scale; social-ecological systems

\section{INTRODUCTION}

The explicit recognition of multiple scales and scaling developed relatively late in the field of ecology (Wiens 1989) and, consequently, in the paradigms traditionally adopted in conservation and environmental management (Palomo et al. 2014). In the last decade, however, conservation has increasingly progressed to consider multiple social and ecological scales (Lengyel et al. 2014, Guerrero et al. 2015, Sayles and Baggio 2017). This progression has been a crucial move toward dealing with problems of scale that have long challenged the ability to manage the environment effectively (Cash and Moser 2000). Scale is defined here as the spatial, temporal, quantitative, or analytical dimensions used to measure and study any phenomenon; level refers to units of analysis that are located at different points on a scale (for example, local and national levels occur along a scale of jurisdictional extent; Cash et al. 2006).

Problems of scale have pervaded many facets of systematic conservation planning, which concerns the process of deciding when, where, and how to allocate constrained resources to conserve biodiversity, ecosystem services, and other valuable attributes of the natural environment (Pressey and Bottrill 2009). Such problems range from technical concerns (e.g., data selection and resolution of priority assessments; Richardson et al. 2006, Hamel et al. 2013, Cheok et al. 2016) to those more strategic in nature (e.g., including social concerns and transitioning from plans to actions; Ban et al. 2013, Pressey et al. 2013, Mills et al. 2014). These technical and strategic concerns in conservation planning often relate to mismatches in scale between social and ecological systems. With the prevalence of scale-related problems in conservation planning, a number of strategies to account explicitly for multiple scales have been proposed in the literature.
Suggested methods include: incorporating scale considerations in conservation triage (Du Toit 2010), evaluating stakeholders at different levels to inform actions (Guerrero et al. 2013, Mills et al. 2014), and integrating ecological data representing different levels (e.g., ecosystems, processes, species) into spatial prioritizations (Squeo et al. 2012, Bombi et al. 2013). Other approaches propose sequential planning processes undertaken at successively higher or lower levels. In scaling up, separate local planning processes are coordinated and placed within a broader context (e.g., Lowry et al. 2009). In scaling down, planning incorporates patterns or processes at progressively finer levels within areas of interest identified initially at broader levels (Groves et al. 2002). Scaling up and scaling down are not without their limitations, with both approaches facing governance and implementation challenges (Lovell et al. 2002, Lowry et al. 2009, Mills et al. 2010, Gaymer et al. 2014). Currently, there is uncertainty about the extent to which lower level (e.g., local) plans are able to address higher level (e.g., national) features and processes or vice versa. This information could be critical to understanding whether scaling down or scaling up is more effective in integrating planning across multiple scales and levels within scales.

Applications of Ostrom's (2009) social-ecological system (SES) framework, in which consideration of multiple scales is implicit, have frequently considered multiple social and ecological scales in environmental management (e.g., Guerrero et al. 2013, Cumming et al. 2015, Virapongse et al. 2016, Guerrero and Wilson 2017). Cumming et al. (2015) adapted Ostrom's (2009) framework to consider multiscale and cross-scale interactions and feedbacks explicitly, and applied this modified framework (hereafter, SES framework; Fig. 1) to assess retrospectively the spatial resilience 
Fig. 1. Social-ecological system (SES) framework reproduced from Cumming et al. (2015) summarizing patterns and processes at different social and ecological scales. The framework integrates Ostrom's (2009) SES framework and Poiani et al.'s (2000) ecological components of a functional landscape. Labels show examples of how social and ecological elements are related to SES components.

\section{ECOLOGICAL LEVEL SOCIAL}

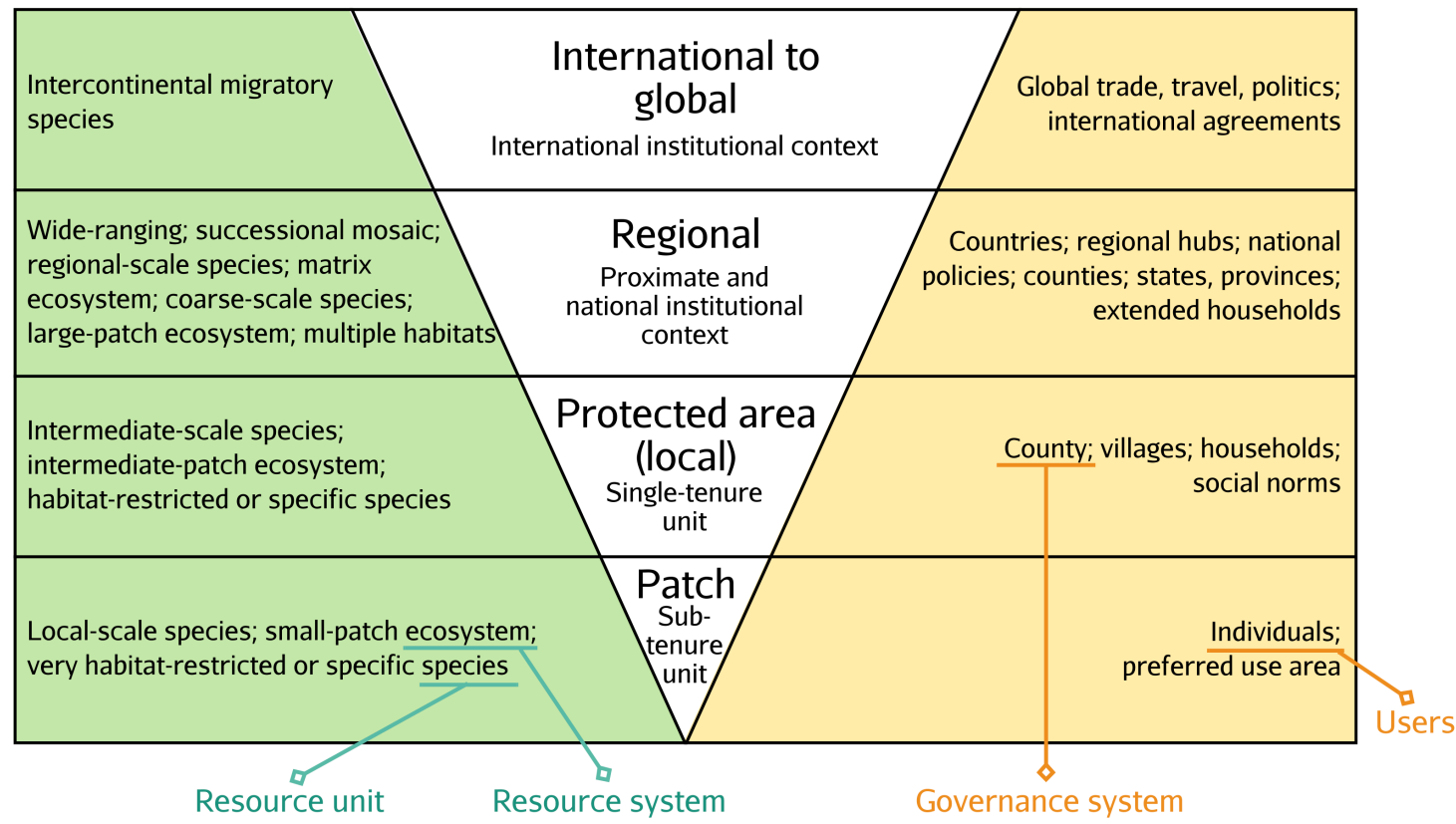

of established protected areas. However, questions remain as to how we can purposefully facilitate successful outcomes across multiple social and ecological scales in conservation planning, and whether there is an optimal level at which planning should occur to achieve success. The principle of subsidiarity, whereby decisions are made at the lowest institutional level capable of executing them sufficiently, has been suggested to guide community-based natural resource management generally (Marshall 2007), and in the western Pacific Ocean's Coral Triangle specifically (Fidelman et al. 2012). However, the capabilities of different institutional levels with respect to conservation planning remain unclear. To address these questions, one must first understand the relative effectiveness of conservation plans developed at different levels to address the social and ecological scales of an SES.

Here, we apply the SES framework depicted in Fig. 1 (Cumming et al. 2015) to assess the extent to which conservation plans developed at one level adequately consider components at various levels across social and ecological scales (hereafter, scalar coverage). By components, we refer to resource units, resource systems, governance systems, and actors of an SES (Ostrom 2009; Fig. 1). As Cumming et al. (2015) demonstrate, each component comprises different elements that occur at a range of levels. For example, the ecological component of resource units can comprise the elements of species and habitats, which occur and function at different levels. The social component of actors can involve the elements of communities, governments, or nongovernmental organizations (NGOs), which also operate at different jurisdictional levels.
The adequacy with which ecological or social elements are considered in conservation plans can be inferred from analyzing specified objectives in the plans (Magris et al. 2014). This is because setting explicit ecological, social, or economic objectives determines how conservation goals and values (related to SES elements) are interpreted in planning processes, within the constraint of available data (Pressey and Bottrill 2009, Ban et al. 2013). While we acknowledge that the objective-setting stage in conservation planning processes is not the only stage wherein scale-related problems can be addressed (e.g., in the implementation stage; see Pressey et al. 2013), our focus on specified objectives of conservation plans offers an evaluation of a key stage in conservation planning: the design phase. Explicit conservation objectives guide the selection of areas for conservation action and, importantly, serve as benchmarks to assess progress toward successful implementation or outcomes (Pressey and Bottrill 2009). For example, ecological objectives might be proportions of certain habitat types (representing the resource system component; e.g., "protect $20 \%$ of fringing reef habitats"). Socioeconomic objectives (including cultural) tend to be more qualitative in nature and, for example, could address community livelihood concerns (representing the actor component; e.g., "maintain sustainable livelihoods for artisanal fisheries").

We use the Coral Triangle region as a case study for our analyses. This region includes all or part of six countries: Indonesia, Papua New Guinea, Philippines, Solomon Islands, Timor Leste, and Malaysia. This region is of particular interest to conservation 
planners because of its global biodiversity importance coupled with highly varied socioeconomic and political complexities (Mills et al. 2010, Fidelman et al. 2012). All but two of the six countries (Malaysia and Timor Leste) have some form of decentralized natural resource governance (decision-making power devolved to local governments or customary clans; Fidelman et al. 2012), for which problems of scale mismatches are known to be acute (Mills et al. 2010).

Ideally, conservation planning within a region would involve the development (and implementation) of plans that amount to complete scalar coverage of an SES, i.e., with all relevant elements adequately addressed at different levels within social and ecological scales. This arrangement is desirable because of the interconnected and multiscale nature of SESs, which makes the management of elements at a single level inadequate (Ban et al. 2013, Maciejewski et al. 2015). Understanding that planning at different levels likely involves varying capacities, we hypothesize that: (1) plans conducted at any particular level will state objectives more adequately for socioeconomic and ecological elements at that same level (hereafter, intralevel objectives) than for those above or below the level of planning (hereafter, extralevel objectives); (2) local-level plans will engage with a greater number of stakeholder groups and consider social factors in more detail than will planning at higher levels; and (3) higher level plans will more adequately address broad-scale ecological elements compared to planning at lower levels. More adequate consideration of intralevel objectives is likely because social and ecological elements occurring at the same level of planning will be easier to conceive and relate to compared to those of other levels (Ostrom et al. 1999, Wyborn and Bixler 2013). Our second and third hypotheses reflect the frequently cited benefits of management stemming from local and regional levels, respectively (Mills et al. 2010, Gaymer et al. 2014). In local or communitybased planning exercises, these benefits are the ability to better incorporate social and economic constraints and stakeholder preferences, whereas in extensive regional planning, these benefits are the available financial and logistical resources to include scientific ecological information (such as species ranges and site connectivity), and the design of managed area networks that are ecologically functional and resilient. It should be noted, however, that these observations do not mean it is impossible for local planning to consider ecological principles or for regional planning to include social or economic dimensions; these perspectives have historically been lacking in marine conservation but are increasingly being addressed (see Ban et al. 2017, Christie et al. 2017).

\section{METHODS}

We first identified marine conservation plans developed at different levels (from patch to international; Fig. 1) from all six countries through searching the peer-reviewed and grey literature. For peer-reviewed literature, we searched the Web of Science database with the following criteria: ("conservation plan*" OR "management plan*") AND ("Coral Triangle" OR "Indonesia" OR "Malaysia" OR "Papua New Guinea" OR "Solomon Islands" OR "Philippines" OR "Timor Leste") AND "marine". This search yielded 80 results, of which only 7 were directly associated with conservation plans. Because of this paucity of results, we extended our search to grey literature using Google Scholar and the same keyword search terms, which yielded 14 additional relevant documents. Our criterion that defined a conservation plan was documentation that reflected the core purposes of conservation planning (Margules and Pressey 2000), considered here as including explicit socioeconomic or ecological objectives (qualitative or quantitative) and identifying spatial boundaries delineating area(s) for some form of management action or as priority areas for future action. Planning levels were categorized on the basis of jurisdictional level rather than spatial extent because the extents of the same levels of jurisdictions (e.g., provinces) can differ greatly between Coral Triangle countries and it is at different jurisdictional levels that conservation actions are applied.

For each conservation plan (Table 1), we first extracted stated ecological and socioeconomic objectives and identified the corresponding ecological and social elements of the SES framework addressed by each objective. The level of each ecological and social element addressed by each stated objective was then classified independently (see Fig. 2 for an overview of the analytical process). The scalar coverage of each plan was determined by assessing the adequacy with which any SES level and relevant social and ecological elements were addressed (detailed below). Assessments of conservation plans were summarized and visualized in R (R Development Core Team 2016) using the $f m s b$ (v0.6.0; Nakazawa 2017) and ggplot2 (Wickham 2009) packages.

\section{Assessing the adequacy with which ecological objectives are addressed}

Each stated objective was first classified in terms of the relevant ecological elements and associated level(s) to which it pertained (step 3, Fig. 2). Classifications were conducted by the lead author and discussed with coauthors for verification where there was uncertainty. We assigned these on the basis of Poiani et al.'s (2000) framework for biodiversity conservation at multiple scales. It can be difficult to assign an ecosystem or species to an exact level because region-specific life-history information is unavailable for most species; moreover, ecological features and phenomena operate at multiple levels within spatial and temporal scales (Levin 1992). Thus, Poiani et al.'s (2000) framework defines the extents of ecological levels generally, with overlapping values between levels to account for regional differences. Informative and specific descriptions of targeted ecosystems or species (e.g., species name, specific habitat information) were missing from many of the conservation plans we assessed. Ecological elements were therefore assigned on the basis of described habitats or processes across the range of levels that might have been encompassed by those described. For example, a common ecological objective was, "Conserve $20 \%$ of shallow marine and coastal habitats (coral reefs, estuaries)". Because coral reef and estuarine habitats in these regions could span patch to local (protected area) levels (Fig. 1; Poiani et al. 2000), this objective would be classified as addressing both patch and local levels.

Each ecological objective was then assessed in terms of whether it was qualitatively or quantitatively articulated. Qualitative objectives were those that described the objective or target without quantitative specification. An example is "include critical or unique sites such as areas with very high diversity, high levels of endemism or unique marine communities". Quantitative objectives involved numerical values when translating an 
Table 1. Summary of all conservation plans and associated reports collated for evaluation of scalar coverage.

\begin{tabular}{|c|c|c|c|c|}
\hline Conservation plan & Plan level & Country & Lead planning organization $^{\dagger}$ & Reference \\
\hline Kakarotan Island Mane'e & Patch & Indonesia & Kakarotan community & Cinner et al. (2005) \\
\hline Muluk Village Traditional Closure & Patch & $\begin{array}{l}\text { Papua New } \\
\text { Guinea }\end{array}$ & Muluk community & Cinner et al. (2005) \\
\hline Nino Sanis Santana Marine National Park & Local & Timor Leste & $\begin{array}{l}\text { Timor Leste Ministry of } \\
\text { Agriculture and Fisheries, } \\
\text { Northern Territory Government, } \\
\text { Charles Darwin University }\end{array}$ & Edyvane et al. (2012) \\
\hline Nusa Penida Marine Protected Area & Local & Indonesia & CTC & Ruchimat et al. (2013) \\
\hline Sinub Island Wildlife Management Area & Local & $\begin{array}{l}\text { Papua New } \\
\text { Guinea }\end{array}$ & WI-O & Jenkins (2002) \\
\hline Tubbataha Reef Natural Park & Local & Philippines & WWF, CI & $\begin{array}{l}\text { Department of Environment } \\
\text { and Natural Resources (2014) }\end{array}$ \\
\hline Tun Mustapha Park & Local & Malaysia & $\begin{array}{l}\text { WWF, UQ, Universiti Malaysia } \\
\text { Sabah }\end{array}$ & Jumin et al. (2018) \\
\hline Wakatobi Marine National Park & Local & Indonesia & TNC, WWF & $\begin{array}{l}\text { Elliott (2001), Clifton (2011, } \\
\text { 2013) }\end{array}$ \\
\hline $\begin{array}{l}\text { Choiseul Province Ridges to Reefs Protected } \\
\text { Area Network }\end{array}$ & Regional & Solomon Islands & TNC, WWF, Live and Learn & Lipsett-Moore et al. (2010) \\
\hline $\begin{array}{l}\text { Isabel Province Ridges to Reefs Protected } \\
\text { Area Network }\end{array}$ & Regional & Solomon Islands & TNC, WWF, WorldFish & Peterson et al. (2012) \\
\hline Kimbe Bay Marine Protected Area Network & Regional & $\begin{array}{l}\text { Papua New } \\
\text { Guinea }\end{array}$ & TNC & Green et al. $(2007,2009)$ \\
\hline $\begin{array}{l}\text { Lesser Sunda Ecoregion Marine Protected } \\
\text { Area Network }\end{array}$ & Regional & Indonesia & $\mathrm{TNC}$ & Wilson et al. (2011) \\
\hline Raja Ampat Marine Protected Area Network & Regional & Indonesia & TNC, WWF, CI & $\begin{array}{l}\text { Agostini et al. (2012), Grantham } \\
\text { et al. (2013) }\end{array}$ \\
\hline $\begin{array}{l}\text { Roviana and Vonavona Lagoons Marine } \\
\text { Protected Area Network }\end{array}$ & Regional & Solomon Islands & $\begin{array}{l}\text { University of California Santa } \\
\text { Barbara, Tiola Conservation } \\
\text { Foundation, WWF, Christian } \\
\text { Fellowship Church }\end{array}$ & Aswani et al. (2005) \\
\hline $\begin{array}{l}\text { Land-Sea Conservation Assessment for Papua } \\
\text { New Guinea }\end{array}$ & Regional & $\begin{array}{l}\text { Papua New } \\
\text { Guinea }\end{array}$ & $\begin{array}{l}\text { Papua New Guinea Conservation } \\
\text { and Environment Protection } \\
\text { Authority, UQ, TNC }\end{array}$ & Adams et al. (2017) \\
\hline $\begin{array}{l}\text { Ridges to Reefs Conservation Plan for } \\
\text { Solomon Islands }\end{array}$ & Regional & Solomon Islands & $\begin{array}{l}\text { Solomon Islands Ministry of } \\
\text { Environment, James Cook } \\
\text { University, TNC }\end{array}$ & Kool et al. (2010) \\
\hline Coral Triangle Marine Protected Area System & International & All & WWF, TNC, CI, UQ & Beger et al. (2013) \\
\hline $\begin{array}{l}\text { Sulu-Sulawesi Marine Ecoregion } \\
\text { Conservation Plan }\end{array}$ & International & $\begin{array}{l}\text { Indonesia, } \\
\text { Malaysia, } \\
\text { Philippines }\end{array}$ & WWF & Dumaup et al. (2003) \\
\hline
\end{tabular}

ecological principle or estimating necessary amounts for conservation. Following Magris et al. (2014), quantitative objectives with no rationale lacked any explicit justification, e.g., " $30 \%$ of each shallow marine habitat (coral reefs, mangroves, seagrass, and estuaries) and its sub-class". Subjective quantitative objectives were based on the opinions of experts, stakeholders, the authors, or on previous work or models but without explicit quantitative ecological justification, e.g., "aim to include at least three representative examples of each habitat type in different locations, distributed over a large area to reduce the chance all would be negatively impacted by a single environmental or anthropogenic event at the same time". Ecologically justified quantitative objectives were based on empirical data, ecological theories, or models employed with supporting ecological information, e.g., "aim for MPAs [marine protected areas] to be spaced 100-200 km apart to maintain genetic connectivity". In our evaluations, quantitative-ecologically justified represented the most adequate level of addressing ecological objectives, and qualitative the least adequate.

\section{Assessing the adequacy with which socioeconomic objectives are addressed}

The socioeconomic objectives of each plan were categorized in terms of their relevant social elements and associated level(s) according to the SES framework (Fig. 1). Socioeconomic objectives were often stated ambiguously, thus potentially spanning multiple levels of actors and governance. For example, "protect high potential tourist sites", could address socio-political and economic factors at multiple levels (e.g., tourist satisfaction occurring at patch and local levels; national revenue generated at regional levels; Cumming et al. 2015). Because of this ambiguity, and because authentic stakeholder involvement underpins the achievement of any conservation objective in societal settings (Pomeroy and Douvere 2008), our assessment of socioeconomic objectives focused on the extent of stakeholder engagement across 
Fig. 2. Overview of the analytical process (adapted from Magris et al. 2014), depicting major steps in analyzing each conservation plan against the social-ecological system (SES) framework. For ecological classifications, qualitative statements (QL) refer to statements of preferences, and quantitative statements were grouped into three classes: no rationale $(\mathrm{QN})$, subjective (QS), or justified ecologically (QE). For socioeconomic classifications, statements were classified to reflect the degree of stakeholder participation involved (adapted from Arnstein 1969, Pomeroy and Douvere 2008), ranging from information (I) to consultation (C), negotiation $(\mathrm{N})$, and delegated power $(\mathrm{P})$.

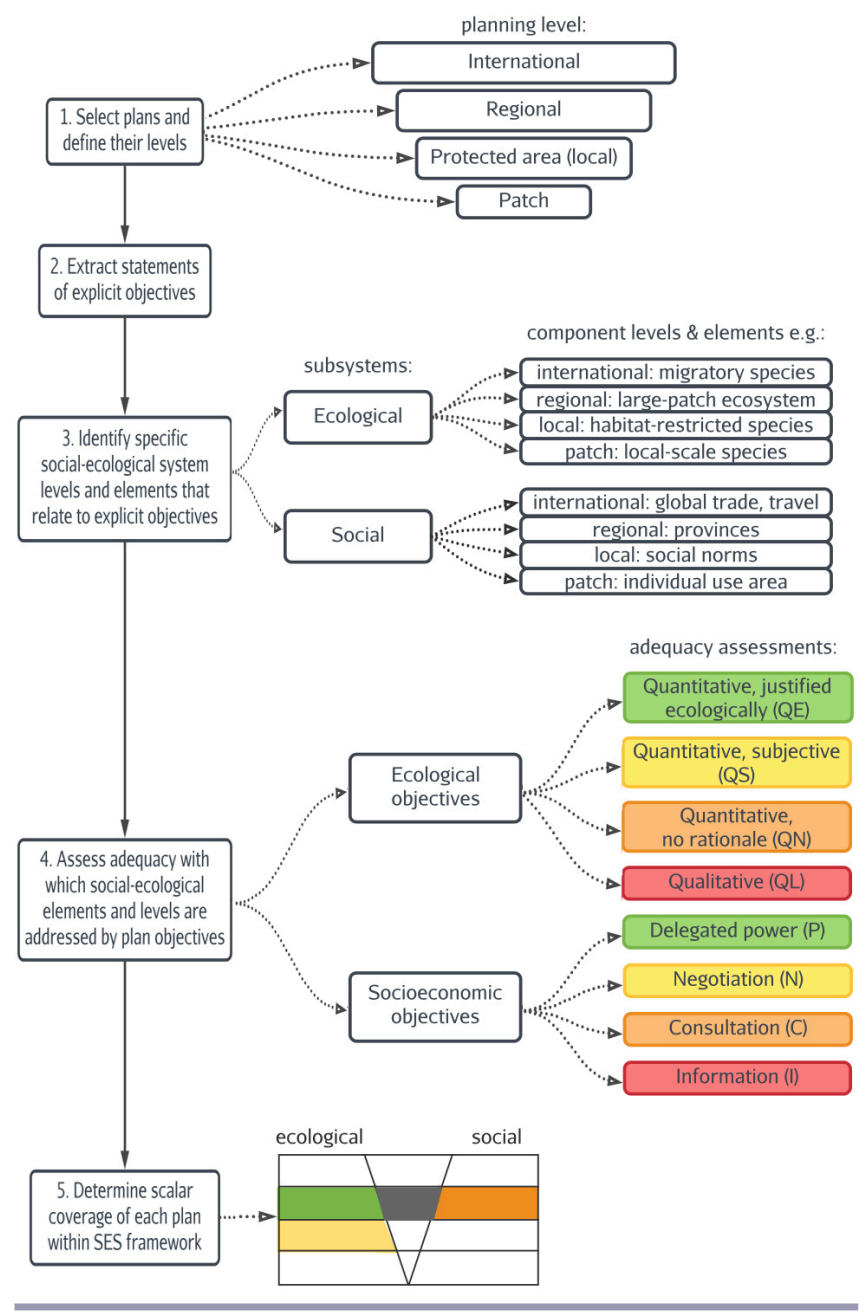

the different levels. We considered stakeholder groups as engaged only if stated socioeconomic objectives explicitly referred to them or if engagement with them was explicitly described in the planning documents or reports.

To assess the degree of stakeholder engagement in planning processes related to stated socioeconomic objectives, we used a classification scheme based on Arnstein's (1969) ladder of citizen participation, adapted in the context of Pomeroy and Douvere's (2008) review of stakeholder participation in marine spatial planning. Stakeholders are defined here as, "individuals, groups or organisations who are, in one way or another, interested, involved or affected (positively or negatively) by a particular project or action toward resources use" (Pomeroy and Douvere 2008). We reviewed all stated socioeconomic objectives in each conservation plan to identify the relevant stakeholder groups and assign respective levels. We recognized the following groups: national government, local government, international NGOs, local NGOs, remote academics, local academics, mining and shipping industry, tourism sector, aquaculture sector, commercial fisheries, subsistence fisheries, traditional leaders, and local communities. These stakeholder groups and corresponding levels were then categorized in terms of their degree of participation: "information", essentially nonparticipation, with flow of information unidirectional from the managing institution(s) to other stakeholders only; "consultation", with stakeholders consulted but whose ideas and feedback are not necessarily considered in the planning process; "negotiation", genuine dialogue and negotiation between stakeholders but final decision making still rests with the managing institution(s); and "delegated power", with full decision-making power delegated to all stakeholders involved in the planning process.

\section{RESULTS}

We identified a total of 18 conservation plans: two each at the patch and international levels, six at the local level, and eight at the regional level (Table 1). Five plans were from Indonesia, four plans each were from Papua New Guinea and Solomon Islands, and one plan each was from Malaysia, Philippines, and Timor Leste. Of the two plans at the international level, one involved all six Coral Triangle countries (Beger et al. 2013) and the other three countries (Indonesia, Malaysia, and Philippines; Dumaup et al. 2003).

\section{Strengths and weaknesses of plans to address intralevel vs. extralevel objectives}

In general, plans included intralevel ecological objectives and all those below the level of the plan (hereafter, sublevels). There was only one exception: one plan did not address ecological objectives at all sublevels (Solomon Islands National Plan, Fig. 3A; Kool et al. 2010). Across all conservation plans, intralevel ecological objectives were addressed more adequately than, or just as adequately as, sublevel objectives from the same plan (Fig. 3A). In the three instances where higher level (i.e., supralevel) ecological objectives were included, these were addressed least adequately (qualitative; Nino Sanis Santana, Sinub Island, and Papua New Guinea National Plans; Fig. 3A). Socioeconomic objectives only ever referenced engagement with stakeholder groups at the same level of planning or below, or none at all (Fig. 3B).

\section{Strengths and weaknesses of plans in addressing ecological and socioeconomic objectives}

Of all plans assessed, 16 included both ecological and socioeconomic objectives. The remaining two plans (which addressed ecological objectives only) were conducted to review existing reserve systems and update spatial priorities (Kool et al. 2010, Beger et al. 2013). Plans typically had the greatest number of ecological objectives formulated at the intralevel (see Appendix 1 for details). In contrast, socioeconomic objectives were most numerous at local and regional levels, irrespective of the level at which the plan was developed (Appendix 1). While the majority 
Fig. 3. Differences in ecological and social levels addressed by conservation plans developed at different levels. IND = Indonesia, PNG = Papua New Guinea, SI = Solomon Islands, PHI = Philippines, TIM = Timor Leste, MAL = Malaysia, CT = Coral Triangle . Inner to outer plot circles represent social-ecological system levels from patch to international, respectively. Solid black lines indicate the respective planning levels for each conservation plan assessed. (A) The maximum ecological adequacy achieved is shown at each social-ecological system level, based on all ecological objectives stated in each plan. Colors indicate classifications of ecological adequacy: $\mathrm{QL}=$ qualitative, $\mathrm{QN}=$ quantitative with no rationale, $\mathrm{QS}=$ quantitative subjective, and $\mathrm{QE}=$ quantitative ecologically justified. (B) Presence of stakeholder engagement at each social-ecological system level across conservation plans developed at different levels. The diversity and extent of stakeholder engagement was highly variable within and across levels; see Fig. 4 for a more detailed representation.

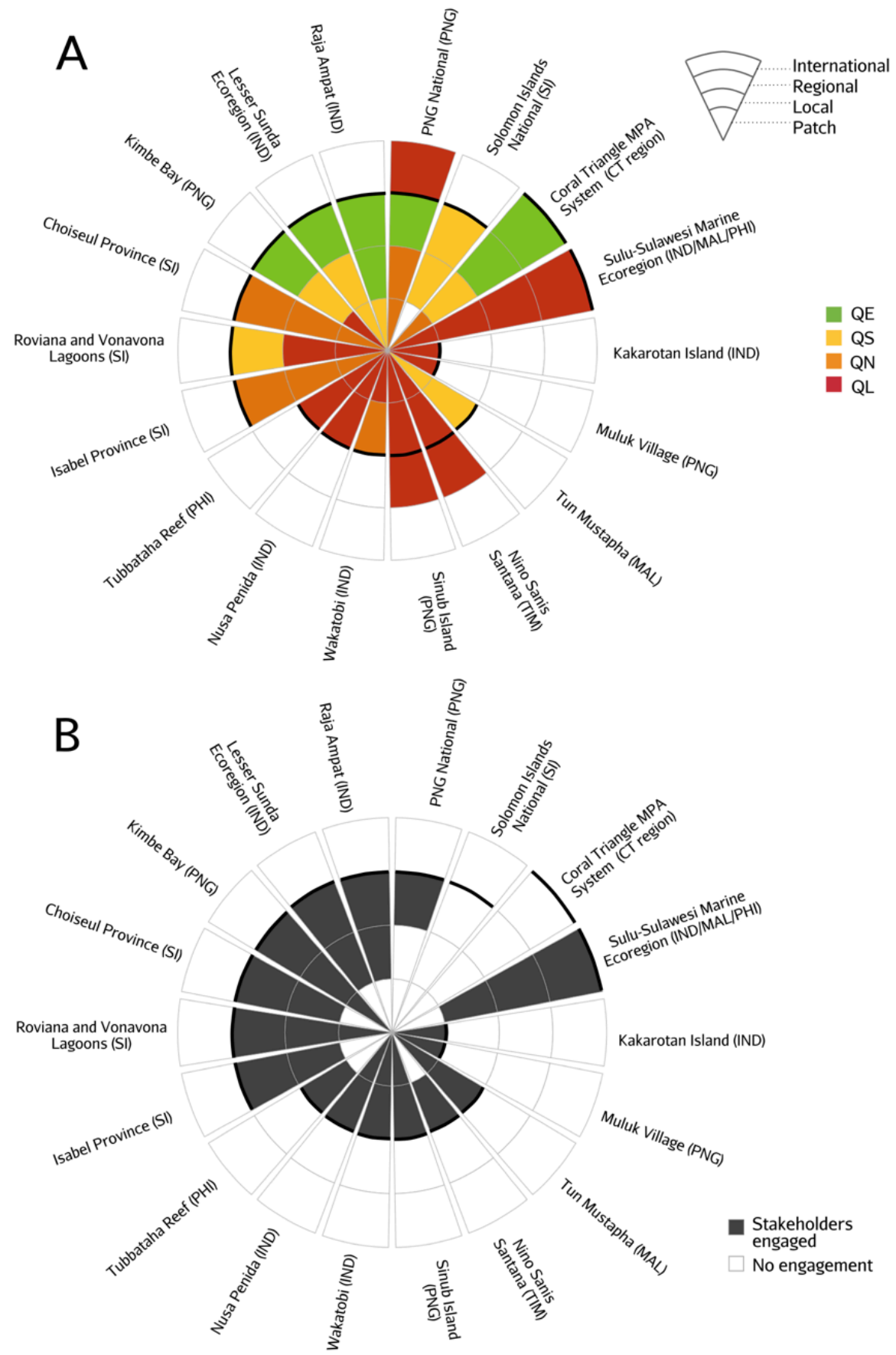


Fig. 4. Differences in the breadth and extent of stakeholder engagement across four social-ecological system planning levels. Engagement refers to different forms of stakeholder engagement; pie charts reflect the variation in engagement among case studies at the same planning level, showing the proportions of the number of case studies and their respective degrees of engagement. Stakeholder groups are ordered by their approximate scale of power or operation: NatGov $=$ national government, LocGov $=$ local government, IntNGO = international nongovernmental organization, LocNGO = local nongovernmental organization, $\mathrm{RemAca}=$ remote academic, LocAca $=$ local academic, Indus $=$ shipping and mining industries sector, Tour $=$ tourism industry sector, Aqua $=$ aquaculture sector, CommFis $=$ commercial fisheries, SubFis $=$ subsistence fisheries, TradLead $=$ traditional leaders, LocComm $=$ local communities.

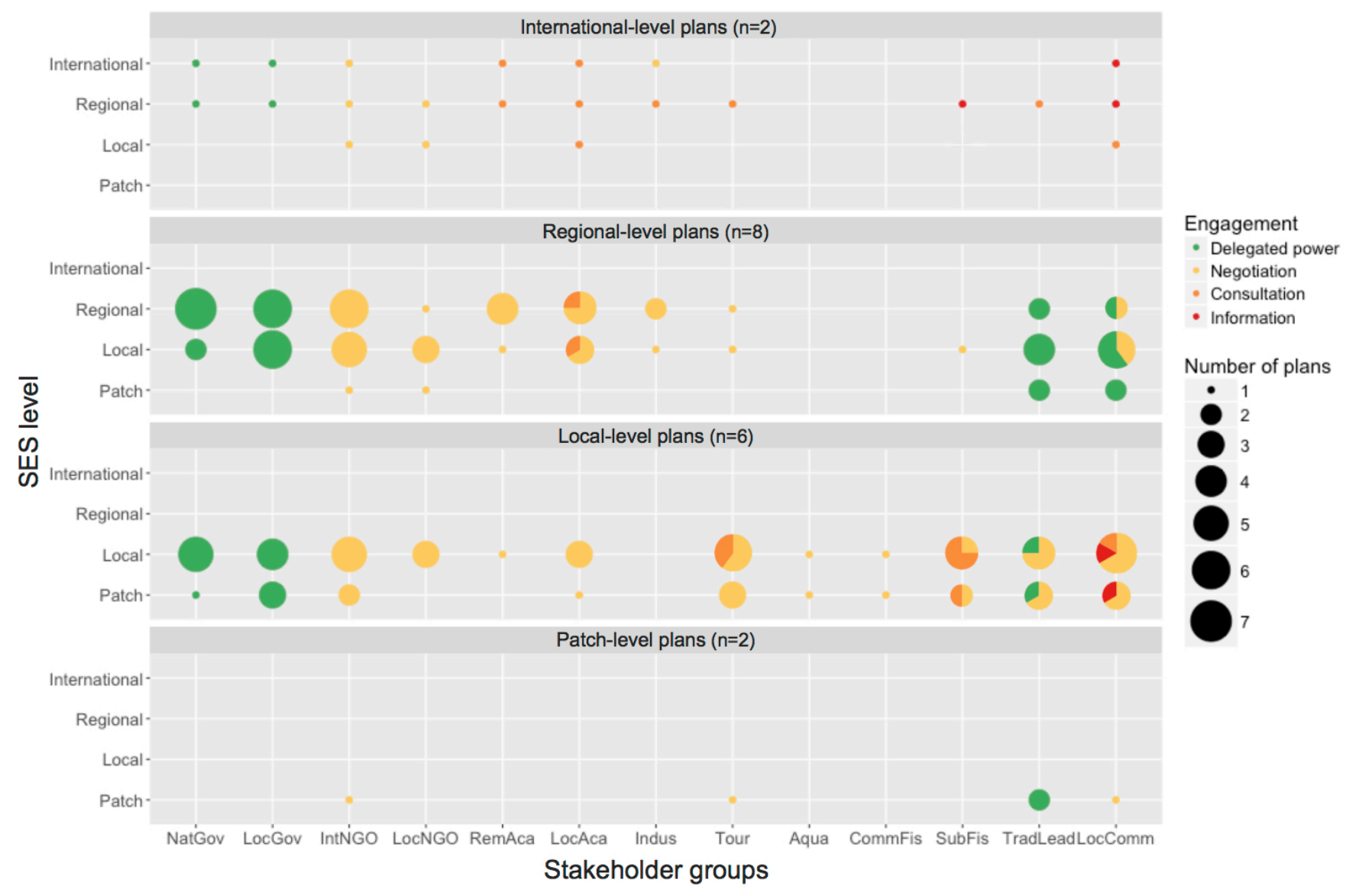

of ecological objectives were stated qualitatively across all plans, there was an inverse relationship between percentage of qualitative objectives and planning level (i.e., percentage of qualitative objectives decreased with increase in planning level; $100 \%, 83 \%, 52 \%$, and $50 \%$, from patch to international levels), and variation in the adequacy with which intralevel objectives were addressed by different plans (with exception of patch-level plans; Fig. 3A).

We found that socioeconomic objectives formulated at different levels were concerned with resource use by, and benefits to, the stakeholder groups that were most relevant at each level. For example, socioeconomic objectives at local levels were primarily concerned with resource use by, and benefits to, local communities (e.g., "protect areas of cultural importance"), whereas those at regional levels involved broader economic concerns, often relating to resource use by, and benefits to, industry (e.g., "support lowimpact environmentally friendly industries that are compatible with MPAs"). All socioeconomic objectives across all conservation plans were stated qualitatively.

Plans regularly included multiple ecological objectives at a single level. For example, in the Wakatobi Marine National Park (Indonesia) plan, two ecological objectives addressed local-level elements, with different degrees of adequacy: (1) "effective management of coral reefs, cetaceans, together with undefined ecologically valuable marine species" (qualitative); and (2) "maintaining existing levels of hard coral cover which are estimated to be around 35-40\%" (quantitative-no rationale). To highlight the potential for plans to address SES elements at different levels, we report the maximum degree of adequacy with which ecological objectives were addressed at each level (Fig. 3A).

In general, we found that, across all identified conservation plans, governments had decision-making power; nongovernmental institutions and industries tended to be negotiated with; and local 
communities and subsistence fisheries were more variably informed, consulted, or negotiated with (Fig. 4). Exceptions to the latter trend occurred in conservation plans from countries with customary resource ownership, where local communities had delegated power (e.g., patch- and regional-level plans in Papua New Guinea and Solomon Islands; Fig. 4). Local-level plans engaged with a more diverse range of stakeholder groups than any other level of planning, but the degree of engagement varied among groups. At the lowest level (i.e., patch), engagement occurred with the least number of stakeholder groups and was less varied compared to other levels of planning (Fig. 4).

\section{DISCUSSION}

Conservation planning problems are inherently uncertain, complex, and multiscale, and thus require multilevel governance approaches (whereby independent centers of decision making exist, often represented by different institutional levels; Morrison 2017). Multilevel governance theoretically offers the advantage of increased SES resilience (where resilience is defined as the capacity of a system to absorb shocks and still maintain function; Folke 2006) through higher adaptive capacities and ability respond better to specific contexts (Biggs et al. 2012, Garmestani and Benson 2013, Gruby and Basurto 2013). Our results provide insights into how we can more comprehensively account for the respective strengths and weaknesses of lower and higher level conservation planning in adequately considering social and ecological scales, and integrate planning processes across levels to maximize scalar coverage within a region.

Our hypothesis that conservation plans will better address intralevel socioeconomic and ecological elements compared to those at extralevels was substantiated to a certain extent by our results. Although all plans we evaluated consistently addressed intralevel objectives more adequately than extralevel objectives, 10 plans addressed sublevel objectives equally well. Our second hypothesis was similarly validated with qualifications. Rather than finding that local-level plans considered social factors in more detail, we found that plans developed at any level (except for patch-level plans) consistently considered the greatest number of socioeconomic objectives at local and regional levels. We also found that local-level plans engaged the greatest number of stakeholder groups. However, the extent of engagement was highly variable across stakeholder groups in all levels of planning except the patch level. Finally, our hypothesis that regional-level plans would address ecological objectives more adequately than local- and patch-level plans was validated.

\section{Apparent strengths and weaknesses of lower level planning}

Our finding that socioeconomic objectives were greatest in number at local and regional levels likely reflects the more directly, and therefore easily, observable social factors and impacts at these levels compared to higher ones (Ban and Klein 2009). The framing of socioeconomic objectives at local levels also better captured, relative to other levels, with social elements representing lower level actors and governance systems (e.g., socioeconomic concerns relevant to local resource users and communities).

Although equitable engagement across all key stakeholders who are not final decision makers is generally ideal (Pomeroy and Douvere 2008), the extent of engagement that is most appropriate across different stakeholder groups is complex and highly context specific (Gopnik et al. 2012, Fox et al. 2013, Sterling et al. 2017). Nonetheless, because our results suggest that local-level plans are better able to engage a greater number of stakeholder groups than are other levels, it is clear that some form of local-level planning is essential. Conversely, patch- and local-level plans generally did not address ecological elements at higher levels and were less able to adequately address these at lower levels (though they were able to address intralevel ecological objectives in a subjective quantitative way), suggesting that local-level planning alone is not sufficient.

Weaknesses in planning at different levels can be described as either conceptual or technical. Lower level plans generally did not include objectives for ecological elements at higher levels, suggesting a conceptual limitation in the ability of planners at lower levels to perceive ecological features and processes that occur at broader extents (e.g., Charlie et al. 2013, Wyborn and Bixler 2013). Scale mismatches between objectives for local protected areas and the need to represent ecological elements occurring at regional and international extents suggest that this type of mismatch produces a lack of local management capacity to address ecological elements at larger extents (Maciejewski et al. 2015). Technical limitations were suggested by the poor adequacy with which ecological elements were addressed, most evident in lower level plans. This technical limitation of lower level planning, typically led by local NGOs in Coral Triangle countries, relates to the lack of technical expertise and capital resources commonly faced by these organizations (Green et al. 2011).

\section{Apparent strengths and weaknesses of higher level planning}

Regional- and international-level conservation plans demonstrated greater capacity to adequately address ecological elements. This is likely because organizations that are leading planning at higher levels (in Coral Triangle countries, typically international NGOs) tend to have greater access to technical resources and expertise, which are necessary to incorporate empirically justified ecological objectives (see Kool et al. 2010, Agostini et al. 2012, Beger et al. 2013). As with local-level plans, higher level planning was important in addressing socioeconomic elements at the same (i.e., regional and international) levels (e.g., concerning development of industries). This result suggests that conservation planning across both lower and higher levels is necessary to ensure that the scalar coverage of social components is maximized for improved outcomes across all levels (Ban et al. 2013).

A common technical limitation of higher level planning is the ability to obtain fine-resolution data necessary to adequately address ecological elements at local levels (Mills et al. 2010). Although the higher level conservation plans we evaluated frequently mentioned this caveat (e.g., Green et al. 2007, LipsettMoore et al. 2010, Beger et al. 2013), we still found that these plans had greatest scalar coverage. However, although our assessment scheme for ecological adequacy favors quantitative objectives, we were unable to determine whether the data used to address the stated quantitative objectives were appropriate or accurate. It is thus possible that the adequacy with which higher level plans considered regional and international elements is overestimated. Nevertheless, our results suggest that it might be possible to overcome the technical and conceptual limitations to some degree in high-level planning. 
The greater scalar coverage achieved with higher level plans could be a reflection of the hierarchical scales that relate to management, social networks, and knowledge (Cash et al. 2006), with higher levels inherently containing within them all entities at lower levels (e.g., Lebel et al. 2008). Moreover, national institutions are supposed to be designed to include and affect factors relevant to lower levels (e.g., flows of capital, economic policies). In contrast, local institutions are seldom, if ever, capable of coping with developments occurring at national or international levels (e.g., civil war, international trade markets; Ostrom et al. 1999).

\section{Recommendations to overcome limitations associated with single- level planning}

From our assessment of conservation plans against the SES framework, the need to plan at multiple levels and integrate across them is clear. Planning at regional levels or higher appears to have greater scalar coverage than plans developed at lower levels, suggesting some support for scaling down processes, with sequential planning occurring at progressively lower levels. The limitations of scaling down primarily relate to the lack of consideration of local contexts (Gaymer et al. 2014). Thus, we suggest that rather than strictly scaling down, a more effective strategy to integrate planning across multiple scales and levels within them might involve initiating planning at a high level (e.g., regional or international), and then iteratively cycling between higher and lower levels of planning (e.g., Pressey et al. 2013). This process would ensure that higher level plans do not proceed to identify priorities and conservation interventions without consideration of relevant local conditions.

There is now significant evidence demonstrating that scale mismatches often decrease the functioning of SESs (Epstein et al. 2015); the larger the magnitude of mismatch, the more likely is a greater loss in system resilience (Maciejewski et al. 2015). Given the clear mismatch between the different planning levels and their ability to consider elements occurring at other levels, one way to overcome their respective limitations is to ensure that planning processes interact and effectively inform one another across levels. This interaction would increase the coverage and alignment of scale-specific perspectives between planning at different levels, which has been asserted as a means to overcoming mismatches between spatial and institutional scales (Maciejewski et al. 2015). Moreover, bridging organizations (i.e., entities that connect social actors or groups) have been demonstrated to enhance alignment across different scales of an SES (e.g., governance, social, ecological) for improved conservation outcomes (such as increasing flexibility in management and decision making, coordination and cooperation among actors, and learning), as well as to facilitate iterative cycling between different levels of governance (Olsson et al. 2007, Crona and Parker 2012, Horigue et al. 2012, Berdej and Armitage 2016).

Our results suggest that the limitations of planning at both lower and higher levels are conceptual and technical in nature, but differently so. Lower level plans are constrained by their ability to conceptualize as well as technically address elements at higher levels, whereas higher level plans are primarily limited by their capacity to address lower level technical ecological elements and to conceptualize higher level socioeconomic objectives. Conceptual and technical limitations might be overcome by different types of interactions between planning processes conducted at different levels. Conceptual limitations could be overcome through workshops designed to share and learn from differences in perspectives between planning levels (e.g., identifying socioeconomic and ecological objectives that are important at different levels). Technical limitations might be mitigated through exchanges of data, information, or individuals possessing the appropriate expertise between processes. Such information sharing between levels needs to be institutionalized for long-term success (Berkes 2009). These interactions across planning levels would be facilitated if planners have greater awareness of conservation plans developed at other levels, in the same region and elsewhere, to broaden their perspectives and so understand the different conceptualizations of socioeconomic and ecological objectives at other levels. This information sharing could be accomplished through a standard database system in which all conservation plans and pertinent planning information (e.g., objectives, data used, socioeconomic and ecological context, implementation strategies) are recorded.

Integrations of SES theory and conservation planning remain limited, mostly theoretical, and largely motivated from a social science perspective (Ban et al. 2013, Mills et al. 2014, Bodin 2017). We argue that the SES framework can also be used as a practical tool for conservation planners to understand the social and ecological elements that may be most relevant to the planning level being undertaken, and elements pertinent at additional levels that should also be considered. The SES framework could also be used by planners to assess the scalar coverage of plans (past or in progress) and identify weaknesses in considering intralevel and extralevel social or ecological elements, as we have done here. This recommendation has relevance to multiple stages of the conservation planning process; beyond setting conservation objectives, the SES framework can also be used to inform the initial scoping stage of planning processes, as well as to evaluate planning outcomes (Pressey and Bottrill 2009).

\section{Limitations}

The main difficulty we found in applying the SES framework to evaluate the strengths and weaknesses of conservation plans was in allocating appropriate levels to the different social and ecological elements addressed by conservation objectives. Because these elements do not fall into discrete levels within spatial or jurisdictional scales, they need to be assigned to a range of levels. We also found that assessing the adequacy of socioeconomic objectives was challenging because, although stakeholders do represent different jurisdictional levels, they can often operate on and influence multiple other levels of an SES. This difficulty was largely related to the ambiguous and qualitative way in which socioeconomic objectives were commonly articulated in conservation plans. A potential improvement to the framework in future applications would involve more explicit inclusion of the elements of governance systems relevant at each SES level. Effective governance is an essential constituent of successful conservation (characterized for example by institutional fit and scale, adaptiveness and learning, coproduction of diverse knowledge; see Armitage et al. 2012), and it is likely that governance systems possessing different characteristics will inherently better address different SES levels (Termeer et al. 2010). A more explicit understanding of governance systems operating at different levels could reveal 
insights into how the scalar coverage of conservation plans can be influenced from a multilevel perspective (e.g., Lebel et al. 2008).

Our study was limited by the number of conservation plans found, particularly at the patch and international levels. A number of factors contributed to this situation. Malaysia and Timor Leste each had only one instance of systematic conservation planning at the time of our analysis (Edyvane et al. 2012, Jumin et al. 2018). In the Philippines, where there is upward of 1200 marine protected areas (Horigue et al. 2012), only one conservation plan could be identified. This discrepancy is likely due to a combination of our criterion for defining conservation plans as requiring documented objectives, and the fact that established protected areas in the Philippines are typically ad hoc patch-level decisions that are not well documented (Alcala and Russ 2006). Further, our assessment of objectives would have been strengthened had conservation plans documented the problem context and values that underlie the specified objectives. We found that this was not the case, highlighting the importance of future plans to report this part of the planning design phase. Our analyses are also limited in that our evaluations relied on planning documentation and reports alone. Causality regarding the presence or absence of objectives had to be inferred, as well as the authenticity of reported stakeholder engagement; further empirical investigation with planners involved in all conservation plans was beyond the scope of this study. Nonetheless, plan documentation plays a vital role in the accountability and transparency of the systematic conservation planning process (Margules and Pressey 2000) and the tracking of progress toward achieving objectives and should thus represent a reliable source of the intentions of any planning process. Finally, important next steps in evaluating the adequacy with which conservation plans address social and ecological levels should focus on realized outcomes from implementation of plans. This perspective would be valuable in contributing insights into, and measuring, the gap between design and implementation stages of conservation planning (Biggs et al. 2011). The lack of implementation of conservation plans ( $\mathrm{Nel}$ et al. 2016), however, would likely further reduce the number of analyzable processes.

\section{CONCLUSION}

We have demonstrated a systematic approach for evaluating the cross-scale coverage of conservation plans developed at different jurisdictional levels and, in doing so, characterize different limitations of plans developed at lower and higher levels. Higher level plans demonstrated a higher capacity for greater scalar coverage (i.e., more social and ecological levels addressed by planning objectives) compared to lower level plans, but with limitations in conceptualizing social objectives. Conversely, social and economic objectives were most commonly formulated at local levels, irrespective of planning level, with local-level plans engaging the greatest number of stakeholder groups. By evaluating the cross-scale coverage of these conservation plans, we also identify specific avenues to overcome the respective limitations and vertically integrate across planning levels. The responsibility for ensuring that plans are vertically integrated across levels lies with the individuals and organizations leading these processes. Achieving this aim requires, at minimum, two critical ingredients. The first is an awareness of other conservation plans developed at different levels, as well as their respective strengths and weaknesses in addressing SES elements (as we have demonstrated and identified here) and potential areas in overlap of scalar coverage between plans. Second, further research is needed to understand specifically how planning processes at different levels can and do inform one another over time to overcome the technical and conceptual limitations associated with planning at a single level.

Responses to this article can be read online at: http://www.ecologyandsociety.org/issues/responses. $\mathrm{php} / 10919$

\section{Acknowledgments:}

We thank Graeme Cumming for very helpful comments on an earlier version of this manuscript. $J C, R W$, and RLP acknowledge funding from the Australian Research Council. JC acknowledges funding from James Cook University.

\section{LITERATURE CITED}

Agostini, V. N., H. S. Grantham, J. Wilson, S. Mangubhai, C. Rotinsulu, N. Hidayat, A. Muljadi, Muhajir, M. Mongdong, A. Darmawan, L. Rumetna, M. V Erdmann, and H. P. Possingham. 2012. Achieving fisheries and conservation objectives within marine protected areas: zoning the Raja Ampat network. The Nature Conservancy, Indo-Pacific Division, Denpasar, Bali, Indonesia. [online] URL: https://www.conservationgateway.org/Files/Pages/ achieving-fisheries-and-c.aspx

Alcala, A. C., and G. R. Russ. 2006. No-take marine reserves and reef fisheries management in the Philippines: a new people power revolution. Ambio 35(5):245-254. https://doi.org/10.1579/05A-054R1.1

Armitage, D., R. de Loë, and R. Plummer. 2012. Environmental governance and its implications for conservation practice. Conservation Letters 5(4):245-255. https://doi.org/10.1111/ j.1755-263X.2012.00238.X

Arnstein, S. R. 1969. A ladder of citizen participation. Journal of the American Institute of Planners 35(4):216-224. https://doi. org/10.1080/01944366908977225

Aswani, S., M. Lauer, P. Weiant, R. Hamilton, and N. B. Tooler. 2005. The Roviana and Vonavona lagoons marine resource management program. University of California, Santa Barbara, California, USA.

Ban, N. C., T. E. Davies, S. E. Aguilera, C. Brooks, M. Cox, G. Epstein, L. S. Evans, S. M. Maxwell, and M. Nenadovic. 2017. Social and ecological effectiveness of large marine protected areas. Global Environmental Change 43:82-91. https://doi. org/10.1016/j.gloenvcha.2017.01.003

Ban, N. C., and C. J. Klein. 2009. Spatial socioeconomic data as a cost in systematic marine conservation planning. Conservation Letters 2(5):206-215. https://doi.org/10.1111/j.1755-263X.2009.00071. $\underline{\mathrm{x}}$

Ban, N. C., M. Mills, J. Tam, C. C. Hicks, S. Klain, N. Stoeckl, M. C. Bottrill, J. Levine, R. L. Pressey, T. Satterfield, and K. M. A. Chan. 2013. A social-ecological approach to conservation 
planning: embedding social considerations. Frontiers in Ecology and the Environment 11(4):194-202. https://doi.org/10.1890/110205

Beger, M., J. McGowan, S. F. Heron, E. A. Treml, A. Green, A. T. White, N. H. Wolff, K. Hock, R. van Hooidonk, P. J. Mumby, and H. P. Possingham. 2013. Identifying gaps in the Coral Triangle Marine Protected Area system as conservation priorities. Coral Triangle Support Program of USAID, The Nature Conservancy, and University of Queensland, Brisbane, Australia. [online] URL: http://www.coraltriangleinitiative.org/library/technical-reportidentifying-gaps-coral-triangle-marine-protected-area-systemconservation

Berdej, S., and D. Armitage. 2016. Bridging for for better conservation fit in Indonesia's coastal-marine systems. Frontiers in Marine Science 3:101. https://doi.org/10.3389/fmars.2016.00101

Berkes, F. 2009. Evolution of co-management: role of knowledge generation, bridging organizations and social learning. Journal of Environmental Management 90(5):1692-1702. https://doi.org/10.1016/ j.jenvman.2008.12.001

Biggs, D., N. Abel, A. T. Knight, A. Leitch, A. Langston, and N. C. Ban. 2011. The implementation crisis in conservation planning: could "mental models" help? Conservation Letters 4(3):169-183. https://doi.org/10.1111/j.1755-263X.2011.00170.X

Biggs, R., M. Schlüter, D. Biggs, E. L. Bohensky, S. BurnSilver, G. Cundill, V. Dakos, T. M. Daw, L. S. Evans, K. Kotschy, A. M. Leitch, C. Meek, A. Quinlan, C. Raudsepp-Hearne, M. D. Robards, M. L. Schoon, L. Schultz, and P. C. West. 2012. Toward principles for enhancing the resilience of ecosystem services. Annual Review of Environment and Resources 37:421-448. https:// doi.org/10.1146/annurev-environ-051211-123836

Bodin, Ö. 2017. Collaborative environmental governance: achieving collective action in social-ecological systems. Science 357(6352):eaan1114. https://doi.org/10.1126/science.aan1114

Bombi, P., M. D’Amen, and L. Luiselli. 2013. From continental priorities to local conservation: a multi-level analysis for African tortoises. Plos One 8(10):e77093. https://doi.org/10.1371/journal. pone.0077093

Cash, D. W., W. N. Adger, F. Berkes, P. Garden, L. Lebel, P. Olsson, L. Pritchard, and O. Young. 2006. Scale and cross-scale dynamics: governance and information in a multilevel world. Ecology and Society 11(2):8. https://doi.org/10.5751/ES-01759-110208

Cash, D. W., and S. C. Moser. 2000. Linking global and local scales: designing dynamic assessment and management processes. Global Environmental Change 10(2):109-120. https://doi. org/10.1016/S0959-3780(00)00017-0

Charlie, C., B. King, and M. Pearlman. 2013. The application of environmental governance networks in small island destinations: evidence from Indonesia and the Coral Triangle. Tourism Planning \& Development 10(1):17-31. https://doi. org/10.1080/21568316.2012.730056

Cheok, J., R. L. Pressey, R. Weeks, S. Andréfouët, and J. Moloney. 2016. Sympathy for the devil: detailing the effects of planningunit size, thematic resolution of reef classes, and socioeconomic costs on spatial priorities for marine conservation. Plos One 11 (11):e0164869. https://doi.org/10.1371/journal.pone.0164869
Christie, P., N. J. Bennett, N. J. Gray, T. A. Wilhelm, N. Lewis, J. Parks, N. C. Ban, R. L. Gruby, L. Gordon, J. Day, S. Taei, and A. M. Friedlander. 2017. Why people matter in ocean governance: incorporating human dimensions into large-scale marine protected areas. Marine Policy 84:273-284. https://doi. org/10.1016/j.marpol.2017.08.002

Cinner, J., M. J. Marnane, T. R. McClanahan, and G. R. Almany. 2005. Periodic closures as adaptive coral reef management in the Indo-Pacific. Ecology and Society 11(1):31. https://doi. org/10.5751/es-01618-110131

Clifton, J. 2011. The Wakatobi National Park - governance analysis. Pages 118-126 in P. J. S. Jones, W. Qiu, and E. M. De Santo, editors. Governing marine protected areas: getting the balance right. Technical Report. United Nations Environment Programme, Nairobi, Kenya. [online] URL: https://www. mpaaction.org/sites/default/files/Jones $\% 20$ et $\%$

20al_2011_Governing\%20MPAs\%20Technical\%20Report.pdf

Clifton, J. 2013. Refocusing conservation through a cultural lens: improving governance in the Wakatobi National Park, Indonesia. Marine Policy 41:80-86. https://doi.org/10.1016/j.marpol.2012.12.015

Crona, B. I., and J. N. Parker. 2012. Learning in support of governance: theories, methods, and a framework to assess how bridging organizations contribute to adaptive resource governance. Ecology and Society 17(1):32. https://doi. org/10.5751/ES-04534-170132

Cumming, G. S., C. R. Allen, N. C. Ban, D. Biggs, H. C. Biggs, D. H. M. Cumming, A. De Vos, G. Epstein, M. Etienne, K. Maciejewski, R. Mathevet, C. Moore, M. Nenadovic, and M. Schoon. 2015. Understanding protected area resilience: a multiscale, social-ecological approach. Ecological Applications 25 (2):299-319. https://doi.org/10.1890/13-2113.1

Department of Environment and Natural Resources. 2014. General management plan, Tubbataha Reefs Natural Park and World Heritage Site (2015-2021). Department of Environment and Natural Resources, Quezon City, Philippines. [online] URL: http://tubbatahareef.org/wordpress/wp-content/uploads/2012/11/ TRNP-General-Mgt-Plan-2015-2021.pdf

Du Toit, J. T. 2010. Considerations of scale in biodiversity conservation. Animal Conservation 13(3):229-236. https://doi. org/10.1111/j.1469-1795.2010.00355.x

Dumaup, J. N. B., R. M. Cola, R. B. Trono, J. A. Ingles, E. F. B. Miclat, and N. P. Ibuna. 2003. Conservation plan for the SuluSulawesi Marine Ecoregion. Stakeholders of the SSME; Technical Working Groups of Indonesia, Malaysia and the Philippines; and the WWF-SSME Conservation Program Team, World Wide Fund for Nature, Quezon City, Philippines. [online] URL: http:// www.reefbase.org/resource center/publication/pub 77335.aspx

Edyvane, K. S., N. de Carvalho, S. Penny, A. Fernandes, C. B. de Cunha, A. L. Amaral, M. Mendes, and P. Pinto. 2012. Conservation values, issues and planning in the Nino Konis Santana Marine Park, Timor Leste - final report. Ministry of Agriculture and Fisheries, Government of Timor Leste, Dili, East Timor.

Elliott, G., B. Mitchell, B. Wiltshire, I. A. Manan, and S. Wismer. 2001. Community participation in marine protected area management: Wakatobi National Park, Sulawesi, Indonesia. 
Coastal Management 29(4):295-316. https://doi.org/10.1080/089207501750475118

Epstein, G., J. Pittman, S. M. Alexander, S. Berdej, T. Dyck, U. Kreitmair, K. J. Rathwell, S. Villamayor-Tomas, J. Vogt, and D. Armitage. 2015. Institutional fit and the sustainability of socialecological systems. Current Opinion in Environmental Sustainability 14:34-40. https://doi.org/10.1016/j.cosust.2015.03.005

Fidelman, P., L. Evans, M. Fabinyi, S. Foale, J. Cinner, and F. Rosen. 2012. Governing large-scale marine commons: contextual challenges in the Coral Triangle. Marine Policy 36(1):42-53. https://doi.org/10.1016/j.marpol.2011.03.007

Folke, C. 2006. Resilience: the emergence of a perspective for social-ecological systems analyses. Global Environmental Change 16(3):253-267. https://doi.org/10.1016/j.gloenvcha.2006.04.002

Fox, E., E. Poncelet, D. Connor, J. Vasques, J. Ugoretz, S. McCreary, D. Monié, M. Harty, and M. Gleason. 2013. Adapting stakeholder processes to region-specific challenges in marine protected area network planning. Ocean and Coastal Management 74:24-33. https://doi.org/10.1016/j.ocecoaman.2012.07.008

Garmestani, A. S., and M. H. Benson. 2013. A framework for resilience-based governance of social-ecological systems. Ecology and Society 18(1):9. https://doi.org/10.5751/ES-05180-180109

Gaymer, C. F., A. V. Stadel, N. C. Ban, P. F. Cárcamo, J. Ierna Jr., and L. M. Lieberknecht. 2014. Merging top-down and bottomup approaches in marine protected areas planning: experiences from around the globe. Aquatic Conservation: Marine and Freshwater Ecosystems 24(S2):128-144. https://doi.org/10.1002/ $\underline{\text { aqc. } 2508}$

Gopnik, M., C. Fieseler, L. Cantral, K. McClellan, L. Pendleton, and L. Crowder. 2012. Coming to the table: early stakeholder engagement in marine spatial planning. Marine Policy 36 (5):1139-1149. https://doi.org/10.1016/j.marpol.2012.02.012

Grantham, H. S., V. N. Agostini, J. Wilson, S. Mangubhai, N. Hidayat, A. Muljadi, Muhajir, C. Rotinsulu, M. Mongdong, M. W. Beck, and H. P. Possingham. 2013. A comparison of zoning analyses to inform the planning of a marine protected area network in Raja Ampat, Indonesia. Marine Policy 38:184-194. https://doi.rg/10.1016/j.marpol.2012.05.035

Green, A., P. Lokani, S. Sheppard, J. Almany, S. Keu, J. Aitsi, J. W. Karvon, R. Hamilton, and G. Lipsett-Moore. 2007. Scientific design of a resilient network of marine protected areas: Kimbe Bay, West New Britain, Papua New Guinea. TNC Pacific Island Countries Report 2/07. The Nature Conservancy, Indo-Pacific Resource Centre, South Brisbane, Australia. [online] URL: https://www.sprep.org/attachments/VirLib/PNG/scientific-designresilient-mpa-network-png.pdf

Green, A., S. E. Smith, G. Lipsett-Moore, C. Groves, N. Peterson, S. Sheppard, P. Lokani, R. Hamilton, J. Almany, J. Aitsi, and L. Bualia. 2009. Designing a resilient network of marine protected areas for Kimbe Bay, Papua New Guinea. Oryx 43(4):488-498. https://doi.org/10.1017/S0030605309990342

Green, S. J., A. T. White, P. Christie, S. Kilarski, A. B. T. Meneses, G. Samonte-Tan, L. B. Karrer, H. Fox, S. Campbell, and J. D. Claussen. 2011. Emerging marine protected area networks in the
Coral Triangle: lessons and way forward. Conservation and Society 9(3):173-188. https://doi.org/10.4103/0972-4923.86986

Groves, C. R., D. B. Jensen, L. L. Valutis, K. H. Redford, M. L. Shaffer, J. M. Scott, J. V. Baumgartner, J. V. Higgins, M. W. Beck, and M. G. Anderson. 2002. Planning for biodiversity conservation: putting conservation science into practice. Bioscience 52(6):499-512. $\underline{\text { https://doi.org/10.1641/0006-3568 }}$ (2002)052[0499:PFBCPC]2.0.CO;2

Gruby, R. L., and X. Basurto. 2013. Multi-level governance for large marine commons: politics and polycentricity in Palau's protected area network. Environmental Science and Policy 33:260-272. https://doi.org/10.1016/j.envsci.2013.06.006

Guerrero, A. M., R. R. J. McAllister, J. Corcoran, and K. A. Wilson. 2013. Scale mismatches, conservation planning, and the value of social-network analyses. Conservation Biology 27 (1):35-44. https://doi.org/10.1111/j.1523-1739.2012.01964.X

Guerrero, A. M., R. R. J. McAllister, and K. A. Wilson. 2015. Achieving cross-scale collaboration for large scale conservation initiatives. Conservation Letters 8(2):107-117. https://doi. org/10.1111/conl.12112

Guerrero, A. M., and K. A. Wilson. 2017. Using a socialecological framework to inform the implementation of conservation plans. Conservation Biology 31(2):290-301. https:// doi.org/10.1111/cobi.12832

Hamel, M. A., S. Andréfouët, and R. L. Pressey. 2013. Compromises between international habitat conservation guidelines and small-scale fisheries in Pacific island countries. Conservation Letters 6(1):46-57. https://doi.org/10.1111/ j.1755-263X.2012.00285.X

Horigue, V., P. M. Aliño, A. T. White, and R. L. Pressey. 2012. Marine protected area networks in the Philippines: trends and challenges for establishment and governance. Ocean and Coastal Management 64:15-26. https://doi.org/10.1016/j.ocecoaman.2012.04.012

Jenkins, A. P. 2002. Sinub Island Marine Wildlife Management Area: plan of management. Wetlands International - Oceania, Riwo Village, Madang Province, Papua New Guinea.

Jumin, R., A. Binson, J. McGowan, S. Magupin, M. Beger, C. J. Brown, H. P. Possingham, and C. Klein. 2018. From Marxan to management: ocean zoning with stakeholders for Tun Mustapha Park in Sabah, Malaysia. Oryx 52(4):775-786. https://doi. org/10.1017/S0030605316001514

Kool, J., T. Brewer, M. Mills, and R. L. Pressey. 2010. Ridges to reefs conservation plan for Solomon Islands. ARC Centre of Excellence for Coral Reef Studies, Townsville, Australia.

Lebel, L., R. Daniel, N. Badenoch, P. Garden, and M. Imamura. 2008. A multi-level perspective on conserving with communities: experiences from upper tributary watersheds in montane mainland Southeast Asia. International Journal of the Commons 2(1):127-154. https://doi.org/10.18352/ijc.29

Lengyel, S., B. Kosztyi, T. B. Ölvedi, R. M. Gunton, W. E. Kunin, D. S. Schmeller, and K. Henle. 2014. Conservation strategies across spatial scales. Pages 133-136 in K. Henle, S. Potts, W. Kunin, Y. Matsinos, J. Simila, J. Pantis, V. Grobelnik, L. Penev, and J. Settele, editors. Scaling in ecology and biodiversity conservation. 
Advanced Books, Pensoft, Sofia, Bulgaria. https://doi. org/10.3897/ab.e1169

Levin, S. A. 1992. The problem of pattern and scale in ecology: the Robert H. MacArthur Award lecture. Ecology 73 (6):1943-1967. https://doi.org/10.2307/1941447

Lipsett-Moore, G., R. Hamilton, N. Peterson, E. Game, W. Atu, J. Kereseka, J. Pita, P. Ramohia, and C. Siota. 2010. Ridges to reefs conservation plan for Choiseul Province, Solomon Islands. TNC Pacific Islands Countries Report 2/10. The Nature Conservancy, Asia-Pacific Resource Centre, South Brisbane, Australia. [online] URL: https://www.conservationgateway.org/ Files/Pages/ridges-reefs-conservation.aspx

Lovell, C., A. Mandondo, and P. Moriarty. 2002. The question of scale in integrated natural resource management. Conservation Ecology 5(2):25. [online] URL: http://www.consecol.org/vol5/ iss $2 / \operatorname{art} 25 /$

Lowry, G. K., A. T. White, and P. Christie. 2009. Scaling up to networks of marine protected areas in the Philippines: biophysical, legal, institutional, and social considerations. Coastal Management 37(3-4):274-290. https://doi. org/10.1080/08920750902851146

Maciejewski, K., A. De Vos, G. S. Cumming, C. Moore, and D. Biggs. 2015. Cross-scale feedbacks and scale mismatches as influences on cultural services and the resilience of protected areas. Ecological Applications 25(1):11-23. https://doi. org/10.1890/13-2240.1

Magris, R. A., R. L. Pressey, R. Weeks, and N. C. Ban. 2014. Integrating connectivity and climate change into marine conservation planning. Biological Conservation 170:207-221. https://doi.org/10.1016/j.biocon.2013.12.032

Margules, C. R., and R. L. Pressey. 2000. Systematic conservation planning. Nature 405(6783):243-253. https://doi.org/10.1038/35012251

Marshall, G. R. 2007. Nesting, subsidiarity, and communitybased environmental governance beyond the local level. International Journal of the Commons 2(1):75-97. http://doi. org/10.18352/ijc. 50

Mills, M., J. G. Álvarez-Romero, K. Vance-Borland, P. Cohen, R. L. Pressey, A. M. Guerrero, and H. Ernstson. 2014. Linking regional planning and local action: towards using social network analysis in systematic conservation planning. Biological Conservation 169:6-13. https://doi.org/10.1016/j.biocon.2013.10.015

Mills, M., R. L. Pressey, R. Weeks, S. Foale, and N. C. Ban. 2010. A mismatch of scales: challenges in planning for implementation of marine protected areas in the Coral Triangle. Conservation Letters 3(5):291-303. https://doi.org/10.1111/j.1755-263X.2010.00134. $\underline{x}$

Morrison, T. H. 2017. Evolving polycentric governance of the Great Barrier Reef. Proceedings of the National Academy of Sciences 114(15):E3013-E3021. https://doi.org/10.1073/pnas.1620830114

Nakazawa, M. 2017. fmsb: functions for medical statistics book with some demographic data. $\mathrm{R}$ package version 0.6.0. [online] URL: https://cran.r-project.org/package $=\mathrm{fmsb}$

Nel, J. L., D. J. Roux, A. Driver, L. Hill, A. C. Maherry, K. Snaddon, C. R. Petersen, L. B. Smith-Adao, H. Van Deventer, and B. Reyers. 2016. Knowledge co-production and boundary work to promote implementation of conservation plans. Conservation Biology 30(1):176-188. https://doi.org/10.1111/ cobi. 12560

Olsson, P., C. Folke, V. Galaz, T. Hahn, and L. Schultz. 2007. Enhancing the fit through adaptive co-management: creating and maintaining bridging functions for matching scales in the Kristianstads Vattenrike Biosphere Reserve, Sweden. Ecology and Society 12(1):28. https://doi.org/10.5751/ES-01976-120128

Ostrom, E. 2009. A general framework for analyzing sustainability of social-ecological systems. Science 325 (5939):419-422. https://doi.org/10.1126/science.1172133

Ostrom, E., J. Burger, C. B. Field, R. B. Norgaard, and D. Policansky. 1999. Revisiting the commons: local lessons, global challenges. Science 284(5412):278-282. https://doi.org/10.1126/ science. 284.5412 .278

Palomo, I., C. Montes, B. Martín-López, J. A. González, M. García-Llorente, P. Alcorlo, and M. R. García Mora. 2014. Incorporating the social-ecological approach in protected areas in the Anthropocene. Bioscience 64(3):181-191. https://doi. org/10.1093/biosci/bit033

Peterson, N., R. Hamilton, J. Pita, W. Atu, and R. James. 2012. Ridges to reefs conservation plan for Isabel Province, Solomon Islands. The Nature Conservancy Indo-Pacific Division, Solomon Islands. [online] URL: https://www.conservationgateway. org/Documents/IR2R\%20Report Aug\%2014\%202012 FINAL small. pdf

Poiani, K. A., B. D. Richter, M. G. Anderson, and H. E. Richter. 2000. Biodiversity conservation at multiple scales: functional sites, landscapes, and networks. Bioscience 50(2):133-146. https:// doi.org/10.1641/0006-3568(2000)050[0133:BCAMSF]2.3.CO;2

Pomeroy, R., and F. Douvere. 2008. The engagement of stakeholders in the marine spatial planning process. Marine Policy 32(5):816-822. https://doi.org/10.1016/j.marpol.2008.03.017

Pressey, R. L., and M. C. Bottrill. 2009. Approaches to landscapeand seascape-scale conservation planning: convergence, contrasts and challenges. Oryx 43(4):464-475. https://doi.org/10.1017/ S0030605309990500

Pressey, R. L., M. Mills, R. Weeks, and J. C. Day. 2013. The plan of the day: managing the dynamic transition from regional conservation designs to local conservation actions. Biological Conservation 166:155-169. https://doi.org/10.1016/j.biocon.2013.06.025

R Development Core Team. 2016. R: a language and environment for statistical computing. R Foundation for Statistical Computing, Vienna, Austria.

Richardson, E. A., M. J. Kaiser, G. Edwards-Jones, and H. P. Possingham. 2006. Sensitivity of marine-reserve design to the spatial resolution of socioeconomic data. Conservation Biology 20(4):1191-1202. https://doi.org/10.1111/j.1523-1739.2006.00426. $\underline{\mathrm{x}}$

Ruchimat, T., R. Basuki, and M. Welly. 2013. Nusa Penida Marine Protected Area (MPA) Bali-Indonesia: Why need to be protected? Transylvanian Review of Systematical and Ecological Research 15 (1):1-9. https://doi.org/10.2478/trser-2013-0016 
Sayles, J. S., and J. A. Baggio. 2017. Social-ecological network analysis of scale mismatches in estuary watershed restoration. Proceedings of the National Academy of Sciences 114(10):E1776E1785. https://doi.org/10.1073/pnas.1604405114

Squeo, F. A., R. A. Estévez, A. Stoll, C. F. Gaymer, L. Letelier, and L. Sierralta. 2012. Towards the creation of an integrated system of protected areas in Chile: achievements and challenges. Plant Ecology and Diversity 5(2):233-243. https://doi. org/10.1080/17550874.2012.679012

Sterling, E. J., E. Betley, A. Sigouin, A. Gomez, A. Toomey, G. Cullman, C. Malone, A. Pekor, F. Arengo, M. Blair, C. Filardi, K. Landrigan, and A. L. Porzecanski. 2017. Assessing the evidence for stakeholder engagement in biodiversity conservation. Biological Conservation 209:159-171. https://doi.org/10.1016/j. biocon.2017.02.008

Termeer, C. J. A. M., A. Dewulf, and M. van Lieshout. 2010. Disentangling scale approaches in governance research: comparing monocentric, multilevel, and adaptive governance. Ecology and Society 15(4):29. https://doi.org/10.5751/ES-03798-150429

Virapongse, A., S. Brooks, E. C. Metcalf, M. Zedalis, J. Gosz, A. Kliskey, and L. Alessa. 2016. A social-ecological systems approach for environmental management. Journal of Environmental Management 178:83-91. https://doi.org/10.1016/j. jenvman.2016.02.028

Wickham, H. 2009. ggplot2: elegant graphics for data analysis. Springer, New York, New York, USA. http://dx.doi. org/10.1007/978-0-387-98141-3

Wilson, J., A. Darmawan, J. Subijanto, A. Green, and S. Sheppard. 2011. Scientific design of a resilient network of marine protected areas: Lesser Sunda ecoregion, Coral Triangle. The Nature Conservancy Asia Pacific Conservation Region, Sanur, Bali, Indonesia. [online] URL: https://www.reefresilience.org/ pdf/LSE_MPA_Design.pdf

Wiens, J. A. 1989. Spatial scaling in ecology. Functional Ecology 3(4):385-397. https://doi.org/10.2307/2389612

Wyborn, C., and R. P. Bixler. 2013. Collaboration and nested environmental governance: scale dependency, scale framing, and cross-scale interactions in collaborative conservation. Journal of Environmental Management 123:58-67. https://doi.org/10.1016/j. jenvman.2013.03.014 
Appendix 1. Additional details of individual case studies.

Table A1.1. Summary of scalar coverage assessed for each conservation plan $(n=18)$, with total number of stated objectives addressing each ecological and social level (path, local, regional, international), and the adequacy with which ecological objectives were addressed. Grey cells indicate the level at which each conservation plan was developed. 


\begin{tabular}{|c|c|c|c|c|c|c|c|c|c|c|c|}
\hline \multirow[b]{4}{*}{ Case study } & \multirow[b]{4}{*}{ Country } & \multirow[b]{4}{*}{ Plan level } & \multirow{4}{*}{$\begin{array}{l}\text { Lead plan } \\
\text { organisation }\end{array}$} & \multirow{2}{*}{\multicolumn{8}{|c|}{ "ECOLOGICAL OBJECTIVES }} \\
\hline & & & & & & & & & & & \\
\hline & & & & \multicolumn{2}{|c|}{$\begin{array}{l}\text { Patch level } \\
\text { Total }\end{array}$} & \multicolumn{2}{|c|}{$\begin{array}{l}\text { Local level } \\
\text { Total }\end{array}$} & \multicolumn{2}{|c|}{$\begin{array}{l}\text { Regional level } \\
\text { Total }\end{array}$} & \multicolumn{2}{|c|}{$\begin{array}{l}\text { International level } \\
\text { Total }\end{array}$} \\
\hline & & & & no. & Adequacy & no. & Adequacy & no. & Adequacy & no. & Adequacy \\
\hline $\begin{array}{l}\text { Sulu-Sulawesi Marine Ecoregion } \\
\text { Plan }\end{array}$ & $\begin{array}{l}\text { Philippines; } \\
\text { Malaysia; } \\
\text { Indonesia }\end{array}$ & International & WWF & 1 & QL & 2 & QL; QL & 3 & QL; QL; QL & 1 & QL \\
\hline $\begin{array}{l}\text { Coral Triangle Marine Protected } \\
\text { Area System }\end{array}$ & Coral Triangle & International & $\begin{array}{l}\text { WWF; TNC; } \\
\text { CI; UQ }\end{array}$ & 1 & QN & 2 & QN; QS & 3 & QE; QE; QS & 3 & QE; QE; QN \\
\hline $\begin{array}{l}\text { Land-Sea Conservation } \\
\text { Assessment for Papua New Guinea }\end{array}$ & Papua New Guinea & Regional & $\begin{array}{l}\text { PNG CEPA; } \\
\text { UQ; TNC }\end{array}$ & 3 & QN; QN; QL & 3 & QN; QN; QL & 2 & QE; QN & 1 & QL \\
\hline $\begin{array}{l}\text { Ridges to Reefs Conservation Plan } \\
\text { for Solomon Islands }\end{array}$ & Solomon Islands & Regional & $\begin{array}{l}\text { SI MoE; JCU; } \\
\text { TNC }\end{array}$ & 0 & & 1 & QS & 1 & QS & 0 & \\
\hline $\begin{array}{l}\text { Lesser Sunda Ecoregion Marine } \\
\text { Protected Area Network }\end{array}$ & Indonesia & Regional & TNC & 2 & QS; QL & 3 & QS; QN; QL & 7 & $\begin{array}{l}\text { QE; QL; QL; QL; } \\
\text { QL; QL; QL }\end{array}$ & 0 & \\
\hline $\begin{array}{l}\text { Raja Ampat Marine Protected Area } \\
\text { Network }\end{array}$ & Indonesia & Regional & $\begin{array}{l}\text { TNC; WWF; } \\
\text { CI }\end{array}$ & 2 & QS; QL & 5 & $\begin{array}{l}\text { QE; QS; QN; } \\
\text { QL; QL }\end{array}$ & 6 & $\begin{array}{l}\text { QE; QL; QL; QL; } \\
\text { QL; QL }\end{array}$ & 0 & \\
\hline $\begin{array}{l}\text { Kimbe Bay Marine Protected Area } \\
\text { Network }\end{array}$ & Papua New Guinea & Regional & $\mathrm{TNC}$ & 1 & QL & 3 & QS; QL; QL & 7 & $\begin{array}{l}\text { QE; QS; QL; QL; } \\
\text { QL; QL; QL }\end{array}$ & 0 & \\
\hline $\begin{array}{l}\text { Choiseul Province Ridges to Reefs } \\
\text { Protected Area Network }\end{array}$ & Solomon Islands & Regional & $\begin{array}{l}\text { TNC; WWF; } \\
\text { LL }\end{array}$ & 4 & $\begin{array}{l}\text { QN; QN; } \\
\text { QL; QL }\end{array}$ & 4 & $\begin{array}{l}\text { QN; QL; QL; } \\
\text { QL }\end{array}$ & 5 & $\begin{array}{l}\text { QN; QN; QL; QL; } \\
\text { QL }\end{array}$ & 0 & \\
\hline $\begin{array}{l}\text { Isabel Province Ridges to Reefs } \\
\text { Protected Area Network }\end{array}$ & Solomon Islands & Regional & $\begin{array}{l}\text { TNC; WWF; } \\
\text { WorldFish }\end{array}$ & 1 & QN & 3 & QN; QL; QL & 4 & QN; QL; QL; QL & 0 & \\
\hline $\begin{array}{l}\text { Roviana and Vonavona Lagoons } \\
\text { Marine Protected Area Network }\end{array}$ & Solomon Islands & Regional & $\begin{array}{l}\text { UCSB; TCF; } \\
\text { WWF; CFC }\end{array}$ & 2 & QL; QL & 1 & QL & 2 & QS; QL & 0 & \\
\hline Wakatobi Marine National Park & Indonesia & Local & TNC; WWF & 1 & QL & 2 & QN; QL & 0 & & 0 & \\
\hline $\begin{array}{l}\text { Nusa Penida Marine Protected } \\
\text { Area }\end{array}$ & Indonesia & Local & CTC & 1 & QL & 2 & QL; QL & 0 & & 0 & \\
\hline Tubbataha Reef Natural Park & Philippines & Local & WWF; CI & 1 & QL & 1 & QL & 0 & & 0 & \\
\hline $\begin{array}{l}\text { Sinub Island Wildlife Management } \\
\text { Area }\end{array}$ & Papua New Guinea & Local & WI-O & 2 & QL; QL & 2 & QL; QL & 1 & QL & 0 & \\
\hline $\begin{array}{l}\text { Nino Sanis Santana Marine } \\
\text { National Park }\end{array}$ & Timor Leste & Local & $\begin{array}{l}\text { MAF; NTG; } \\
\text { CDU }\end{array}$ & 2 & QL; QL & 4 & $\begin{array}{l}\text { QL; QL; QL; } \\
\text { QL }\end{array}$ & 2 & QL; QL & 0 & \\
\hline Tun Mustapha Park & Malaysia & Local & $\begin{array}{l}\text { WWF; UQ; } \\
\text { UMS }\end{array}$ & 3 & QS; QN; QL & 3 & QS; QN; QL & 0 & & 0 & \\
\hline Kakarotan Island Mane'e & Indonesia & Patch & $\begin{array}{l}\text { Kakarotan } \\
\text { community }\end{array}$ & 2 & QL; QL & 0 & & 0 & & 0 & \\
\hline Muluk Village Traditional Closure & Papua New Guinea & Patch & $\begin{array}{l}\text { Muluk } \\
\text { community }\end{array}$ & 1 & QL & 0 & & 0 & & 0 & \\
\hline
\end{tabular}


Table A2.1. continued

\begin{tabular}{|c|c|c|c|c|c|c|c|}
\hline \multirow[b]{2}{*}{ Case study } & \multirow[b]{2}{*}{ Country } & \multirow[b]{2}{*}{ Plan level } & \multirow[b]{2}{*}{ Lead plan organisation* } & \multicolumn{3}{|c|}{ SOCIOECONOMIC OBJECTIVES } & \multirow[b]{2}{*}{$\begin{array}{l}\text { International } \\
\text { Total no. }\end{array}$} \\
\hline & & & & $\begin{array}{l}\text { Patch } \\
\text { Total no. }\end{array}$ & $\begin{array}{l}\text { Local } \\
\text { Total no. }\end{array}$ & $\begin{array}{l}\text { Regional } \\
\text { Total no. }\end{array}$ & \\
\hline Sulu-Sulawesi Marine Ecoregion Plan & Philippines; Malaysia; Indonesia & International & WWF & 0 & 4 & 5 & 2 \\
\hline Coral Triangle Marine Protected Area System & Coral Triangle & International & WWF; TNC; CI; UQ & 0 & 0 & 0 & 0 \\
\hline $\begin{array}{l}\text { Land-Sea Conservation Assessment for Papua } \\
\text { New Guinea }\end{array}$ & Papua New Guinea & Regional & PNG CEPA; UQ; TNC & 1 & 4 & 5 & 0 \\
\hline $\begin{array}{l}\text { Ridges to Reefs Conservation Plan for Solomon } \\
\text { Islands }\end{array}$ & Solomon Islands & Regional & SI MoE; JCU; TNC & 0 & 0 & 0 & 0 \\
\hline $\begin{array}{l}\text { Lesser Sunda Ecoregion Marine Protected Area } \\
\text { Network }\end{array}$ & Indonesia & Regional & $\mathrm{TNC}$ & 5 & 6 & 3 & 0 \\
\hline Raja Ampat Marine Protected Area Network & Indonesia & Regional & TNC; WWF; CI & 4 & 10 & 3 & 0 \\
\hline Kimbe Bay Marine Protected Area Network & Papua New Guinea & Regional & TNC & 5 & 10 & 1 & 0 \\
\hline $\begin{array}{l}\text { Choiseul Province Ridges to Reefs Protected } \\
\text { Area Network }\end{array}$ & Solomon Islands & Regional & TNC; WWF; LL & 0 & 2 & 2 & 0 \\
\hline $\begin{array}{l}\text { Isabel Province Ridges to Reefs Protected Area } \\
\text { Network }\end{array}$ & Solomon Islands & Regional & TNC; WWF; WorldFish & 0 & 1 & 1 & 0 \\
\hline $\begin{array}{l}\text { Roviana and Vonavona Lagoons Marine } \\
\text { Protected Area Network }\end{array}$ & Solomon Islands & Regional & UCSB; TCF; WWF; CFC & 1 & 4 & 2 & 0 \\
\hline Wakatobi Marine National Park & Indonesia & Local & TNC; WWF & 1 & 1 & 0 & 0 \\
\hline Nusa Penida Marine Protected Area & Indonesia & Local & $\mathrm{CTC}$ & 1 & 1 & 1 & 0 \\
\hline Tubbataha Reef Natural Park & Philippines & Local & WWF; CI & 0 & 4 & 0 & 0 \\
\hline Sinub Island Wildlife Management Area & Papua New Guinea & Local & WI-O & 1 & 2 & 1 & 0 \\
\hline Nino Sanis Santana Marine National Park & Timor Leste & Local & MAF; NTG; CDU & 0 & 6 & 0 & 0 \\
\hline Tun Mustapha Park & Malaysia & Local & WWF; UQ; UMS & 1 & 2 & 0 & 0 \\
\hline Kakarotan Island Mane'e & Indonesia & Patch & Kakarotan community & 1 & 0 & 0 & 0 \\
\hline Muluk Village Traditional Closure & Papua New Guinea & Patch & Muluk community & 1 & 0 & 0 & 0 \\
\hline
\end{tabular}

* Lead planning organisations: World Wide Fund for Nature (WWF); The Nature Conservancy (TNC); Conservation International (CI); University of Queensland (UQ); Papua New Guinea

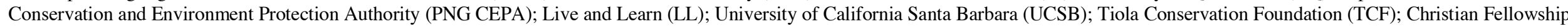
Church (CFC); Coral Triangle Centre (CTC); Wetlands International - Oceania (WI-O); Timor Leste Ministry of Agriculture and Fisheries (MAF); Northern Territory Government (NTG); Charles Darwin University (CDU); Universiti Malaysia Sabah (UMS). 